Annuaire suisse de politique de développement

26-2 | 2007

Financer le développement par la mobilisation des ressources locales

\title{
Entry of Foreign Banks in India and China
}

\section{Kavaljit Singh}

\section{(2) OpenEdition}

\section{Journals}

Electronic version

URL: http://journals.openedition.org/aspd/134

DOI: $10.4000 /$ aspd. 134

ISSN: 1663-9669

Publisher

Institut de hautes études internationales et du développement

\section{Printed version}

Date of publication: 1 November 2007

Number of pages: 121-124

ISBN: 978-2-88247-068-3

ISSN: $1660-5934$

Electronic reference

Kavaljit Singh, "Entry of Foreign Banks in India and China », Annuaire suisse de politique de

développement [En ligne], 26-2 | 2007, mis en ligne le 19 juin 2009, consulté le 07 septembre 2020

URL : http://journals.openedition.org/aspd/134 ; DOI : https://doi.org/10.4000/aspd.134 


\title{
Entry of Foreign Banks in India and China
}

\author{
Kavaljit Singh*
}

|

mplemented in conjunction with other macroeconomic policy reforms, financial liberalization remains one of the most controversial issues in economic literature. Financial liberalization is a process in which allocation of resources is determined by market forces rather than the state. It minimizes the role of the state in the financial sector by encouraging market forces to decide who gets and gives credit and at what price. Banking sector liberalization is an important component of financial liberalization.

While making a strong case in favour of banking sector liberalization, its proponents claim that the entry of foreign banks in the poor and developing world is highly desirable and beneficial. ${ }^{1}$ But recent empirical evidence suggests that the entry of foreign banks could lead to misallocation of credit, which in turn could negatively affect economic growth prospects as bank credit is a vital input for investment and growth. ${ }^{2}$ Big foreign banks are not going to lend money to small and medium-sized enterprises (SMEs), small traders, informal sector and farmers. They tend to serve less risky businesses such as transnational corporations (TNCs) and big corporate groups. This has serious consequences for economic growth. In most countries, whether it is India, China,
Japan, Germany or US, it is the SMEs (not big business) which are the backbone of economy.

At present, the focus of the global banking industry appears to be on India and China, so it becomes important to analyze some of the recent developments taking place in these countries. Let us begin with India. Instead of liberalization pushing the opening of more bank branches in country, one finds that the trend is opposite. The total number of bank branches has declined, particularly in the rural areas (from 32,939 in March 1997 to 32,227 in 2004) in the post-liberalization period. ${ }^{3}$

More importantly, the Indian banking sector has witnessed a secular decline in rural credit. The rural credit went down from 15.7 percent in 1992 to 11.8 percent in $2002 .{ }^{4}$ So the entry of foreign banks has not led to increased rural credit. On the other hand, one finds that there is a growing interest among foreign banks to provide credit for non-essential items such as consumer goods. This situation could be gauged from the fact that car loans come cheaper than agricultural loans in India.

In the post-liberalization period, one also finds that the lending to small and medium enterprises has declined from 15 percent in 1991 to

\footnotetext{
* Director, Public Interest Research Centre, New Delhi. Author of several books including Questioning Globalization (London, Zed Books, 2005), Taming Global Financial Flows (London, Zed Books, 2000). His latest book is Why Investment Matters: The Political Economy of International Investments (London; Brussels, FERN; Sturminster Newton [UK], The Corner House; Rome, Campagna per la riforma della Banca Mondiale [CRBM]; Delhi, Madhyam Books, 2007).

This note was prepared by the author in March 2006 for discussion among activists and campaigners associated with BankTrack.

1 Benson Kunjukunju, "Reforms in Banking Sector and Their Impact in Banking Services," SAJOSPS, July-December 2006, pp. 77-81.

2 Christian Weller, The Connection between More Multinational Banks and Less Real Credit in Transition Economies, ZEI Working Paper, no. B8, Bonn, Center for European Integration Studies, 1999.

3 Kavaljit Singh, "Banking Sector Liberalization in India: Some Disturbing Trends", Asia-Europe Dialogue Project, 2005, $<$ http://www.ased.org>

4 lbid.
} 
11 percent in 2003. ${ }^{5}$ SMEs are the engines of India's economic growth; together they contribute 40 percent of India's total production, 34 percent of exports and are the second largest employer after agriculture. ${ }^{6}$ The growing neglect of bank lending to SMEs can have adverse implications on economic growth and employment.

In the case of China, the earlier strategy of limited financial liberalization has been turned upside down by WTO (World Trade Organization) dictated timetables for rapid liberalization in the banking, securities and insurance sectors. ${ }^{7}$ Several major concessions have been granted by China to foreign banks under the WTO deal. Foreign banks have been allowed to conduct all types of foreign exchange transactions with foreign clients immediately upon accession to the WTO in 2001 while there would be no geographical and client restrictions on foreign banks to operate in China by the year 2006. This would give a major boost to the foreign banks as they have been waiting to capture the banking markets of China, which have almost a trillion dollars in personal savings. In particular, foreign banks are going to capture markets in those regions (e.g., coastal regions and cities) where the bulk of banking business is concentrated.

In China, big foreign banks such as Citigroup and HSBC have already made inroads into wealth market by targeting owners of foreign exchange, including local businessmen and expatriates, who have a minimum of US $\$ 50,000$ in liquid assets. ${ }^{8}$ According to banking industry estimates, the total liquid assets held by wealthy Chinese households (excluding those with less than US $\$ 100,000$ ) are set to nearly double to US $\$ 1,606$ billion by 2009 , up from US $\$ 825$ billion in 2004. No wonder, a number of global banks have lined up to tap local currency wealth business opportunities in China. Big banks such as HSBC and Citigroup would start fully licensed branches by the end of 2006 while Credit Suisse and UBS are expected to open several branches in the next two years.

Given the fact that foreign banks have considerable international exposure and can launch new products (e.g., ATM, credit card, etc.) besides providing better services, they are in an advantageous position to capture China's banking businesses. Foreign banks are also going to dominate the highly lucrative traderelated businesses.

The opening up of the Chinese banking sector would pose no immediate threat to the big four state-owned banks because they have vast branch networks in both urban and rural areas. But the worst sufferers of opening up would be small and medium-sized commercial banks in China. These banks provide credit to small and medium-sized companies in China who are the engines of economic growth in China. Therefore, it seems likely that less credit would be available to small and medium-sized companies in future, which, in turn, would have negative repercussions on the economic growth.

Further, by allowing foreign banks to offer banking services to residents, Chinese elites may be induced to move their savings from state-owned banks to foreign banks that can offer efficient services and new products. It has been estimated that about 10 to 15 percent of savings in state banks would move to foreign banks. Given the fact that the survival of many state-owned enterprises (SOEs) depends on getting loans from the state banks, such a shift of savings could pose a severe threat to the entire economy. If such a massive shift in banking occurs within a short period, the state banks won't be able to support the SOEs, and as a result many SOEs may go bankrupt.

At the consumer level, foreign banks have a bias towards providing services to wealthy

\footnotetext{
5 Ibid.

6 Ibid.

7 For details, see, Kavaljit Singh, “From Beijing Consensus to Washington Consensus: China's Journey to Liberalization and Globalization," Asia-Pacific Research Network, 2002, <http://www.aprnet.org>.

8 Heather Timmons, "Big Banks Rushing to Cheque in," The Hindu Business Line, April 22, 2007.
} 
and affluent customers in the developing world. The upmarket retail business is the primary focus of foreign banks in most developing countries. For instance, consumer retail loans (which are also the riskier) are the fastest growing financial services market in India. ${ }^{9}$ The poor and middle class households are not the attention of foreign banks. In both China and India, foreign banks are entering to provide a wide-ranging advisory service to meet the investment and financial planning needs of affluent customers. Some international banks even provide "lifestyle benefits" such as access to exclusive clubs, concierge services and leisure activities to their customers in India.

Foreign banks tend to follow "exclusive banking" by offering services to a small number of clients, instead of "inclusive banking". ${ }^{10}$ Not only foreign banks charge higher fees from customers for providing banking services but maintaining a bank account requires substantial financial resources. Take the case of Deutsche Bank which re-entered retail banking operations in seven cities of India in 2005. The Deutsche Bank opens bank accounts for those Indian citizens who could afford a minimum balance of Rs. 200,000 (approx. US \$5,000) in their accounts with the bank. This is a princely sum by the Indian income standards, which only affluent customers can afford. The bias towards affluent customers is evident from the statement issued by Mr. Rainer Neske, a member of the Group Executive Committee of Deutsche Bank. At the launch of retail banking operations in India, Mr. Neske stated, "As the leading retail banking provider in Germany and parts of Europe, we have keenly followed the developments in India - one of the most exciting growth markets in the world. The number of affluent Indian consumers is increasing, the market for consumer goods is expanding and private customers' demand for excellent advi- sory services and high quality banking products continues to rise. This is an exciting market that Deutsche Bank seeks to serve by providing advanced value, innovation and convenience to Indian customers." 11

So we need to ask the following questions: Are foreign banks going to meet the developmental needs of unbanked regions in India, as there are 391 under-banked districts (out of a total 602 administrative districts) in India? Are foreign banks going to augment the reach of the banking system to millions of Indian and Chinese citizens who do not have bank accounts? Given the fact that the average private banking customer can be ten times more profitable than the average mass-market retail customer, it is highly unlikely that the commercial interests of foreign banks would match with the developmental needs of unbanked regions of both India and China. Also, one cannot expect that foreign banks would voluntarily open branches in rural and remote regions of India and China as part of altruistic motives or corporate social responsibility measures. This anomaly could only be addressed by a strong regulatory framework, which unfortunately both Indian and Chinese authorities are loosening under the banking liberalization programme.

In the US and South Africa, banks have started giving attention to the unbanked market as their "mainstream" already-banked market has become highly saturated. ${ }^{12}$ In India too, there is a huge untapped market which could be explored by foreign banks. There are 500 million Indians (almost twice the size of US population) who do not enjoy access of banking services. More than altruistic reasons, such a big market size should be attractive to foreign banks. There is no denying that this market is different from others in the sense that banks need to tailor specific products at a lower cost

9 Niranjan Rajadhyaksha, "The Dark Side of Consumer Credit," Businessworld, October 2, 2006, p. 46.

10 EPW Research Foundation, "Financial Inclusion in a Deregulated Regime," Economic and Political Weekly, May 20, 2006, pp. 1940-42.

11 Quoted in the press release, "Deutsche Bank Launches Retail Banking Operations in India," October 18, 2005, Mumbai, Deutsche Bank, <http://www.db.com/ir/en/content/ir_releases_2005.htm>.

12 "Americans without Bank Accounts: Into the Fold," The Economist, May 6, 2006, pp. 72-73. "South Africa's Banks: Banking on the Unbanked," The Economist, May 28, 2005, p. 77. 
to serve this population. But the moot point is that it is not the lack of market which is hindering the delivery of banking services by foreign banks but their bias against the rural sector and poor people in general.

In this context, it is also important to stress here that much-touted microcredit programmes launched by self-help groups and NGOs are no substitute for the formal banking system in India. ${ }^{13}$ With only 15 million clients (the second largest in the world after Bangladesh with 16 million), microcredit programmes till date have only reached a fraction of under-banked population in India. Several studies have questioned the developmental impacts of microcredit programmes as it has been found that their transaction costs are very high and often much of credit is used for consumption purposes rather than investment in productive activity. At best, microcredit programmes can complement, not substitute, the formal banking system to meet the growing credit needs of farmers, rural entrepreneurs, small enterprises and informal sectors of Indian economy. While in the case of China, microcredit programmes have yet to emerge on a larger scale.

13 For details, see, Kavaljit Singh, “Microcredit Misses the Target," Indian Express, May 26, 1997. 